\title{
DOKTRYNALNE PODSTAWY KRAKOWSKIEGO KONCYLIARYZMU ŚREDNIOWIECZNEGO
}

O koncyliaryzmie napisano już dużo. Tego typu twórczość piśmiennicza wzrosła jeszcze bardziej po soborze watykańskim drugim. Przy tym znamienne jest to, że nowe prace na ten temat pojawiły się tak w kraju ${ }^{1}$, jak i za granica ${ }^{2}$. W omawianym artykule chodzi tylko o koncyliaryzm późnośredniowieczny, zwłaszcza o tę jego odmianę, która utrzymywała się na Uniwersytecie Krakowskim w pierwszej połowie XV wieku. Na temat niektórych jego historycznych aspektów istnieją źródła ${ }^{3}$ i duża literatura ${ }^{4}$. W dotychczasowych opracowaniach unikało się jednak rozważań dotyczących doktrynalnych podstaw późnośredniowiecznego koncyliaryzmu. Takie postępowanie jest w jakiejś mierze usprawiedliwione. Doktrynalne źródła koncyliaryzmu są bowiem niewidoczne, gdyż toną w nawale innych ważnych

${ }^{1} \mathrm{~S} . \mathrm{S}$ w i e ża w s k i, Dzieje filozofii europejskiej w XV wieku. I: Poznanie, Warszawa 1974; tenze, Conséquences morales et politiques du conciliarisme médiéval. W: Société et Eglise. Textes et discussions dans les universités d'Europe centrale pendant le moyen âge tardive. Actes du Colloque international de Cracovie 14-16 juin 1993. Wyd. S. W 1 o de k, Turnhout 1995, s. 1-20; J. Kło c z ow s k i, Le conciliarisme à l'université de Cracovie au $X V^{e}$ siècle et ses prolongements au $X V I^{e}$ siècle, „Kyrkohistorisk Arsskrift”, 77:1977, s. 223-226; J. D r a b i n a, Konziliarismus an der Krakauer Universität in der ersten Hälfte des XV. Jahrhunderts. W: Société et Eglise..., s. 117-131; M. M a r k ow sk i, Uniwersytet Krakowski wobec idei soborowej w XV wieku. W: Jubileusz sześćsetlecia Wydziatu Teologicznego w Krakowie $20 \times 1996-20 \times 1997$. Pod red. A. Kubisia, J. Moraw y, S. P o s taw y, Kraków 1998, s. 505-534 (= Studia do dziejow Wydziału Teologicznego Uniwersytetu Jagiellońskiego, X).

${ }^{2}$ P. W. K n o 11, Poland as Antemurale christianitatis in the Late Middle Ages. „Catholic Historical Review", 60:1974, s. 381-401; tenże, The University of Cracow and the Conciliar Movement. W: Rebirth, Reform and Resilience. Universities in Transition 1300-1700. Wyd. ed. J. M. Kittels o n, P. J. Transue, Columbus 1984, s. 190-212; T. W ü n s ch, Konziliarismus und Polen. Personen, Politik und Programme aus Polen zur Verfassungsfrage der Kirche in der mittelalterlichen Reformkonzilien, Paderborn, München, Wien, Zürich 1998 (Konziliengeschichte, hrsg. von W. Brandmüller, Reihe B: Untersuchungen).

\footnotetext{
${ }^{3}$ Tamże, s. XIII-XXIX.

${ }^{4}$ Tamże, s. XXX-LXXXVII.
} 
spraw. Stąd ich wydobycie jest wielce utrudnione. Zadanie tego artykułu o doktrynalnych podstawach krakowskiego koncyliaryzmu pierwszej połowy XV wieku sprowadza się do zwrócenia uwagi na niektóre aspekty podstaw filozoficznych i teologicznych tego potężnego prądu reformatorskiego.

Klasyczne średniowiecze przekazało obraz łacińskiej jedności chrześcijańskich narodów, określonej mianem christianitas, w której istniał uniwersalny związek ludzi i w której Kościół i państwo tworzyły jedność. Jej uniwersalizm zaś przejawił się szczególnie we wyznawanym przez wszystkich ludzi światopoglądzie chrześcijańskim, ponadnarodowym papiestwie, ponadpaństwowym cesarstwie, jednolitej kulturze łacińskiej i ustalonym szkolnym sposobie nauczania.

Następstwem politycznego konfliktu papieża Bonifacego VIII (1294-1303) i francuskiego króla Filipa IV Pięknego (1285-1314) było najpierw załamanie się siły papiestwa, a później awiniońska niewola papieży (1309-1377) i wielka schizma zachodnia $(1378-1417)^{5}$. Gdy tej tragedii zachodniego chrześcijaństwa, nie dało się rozwiązać ani na arenie państwowej, ani na niwie kościelnej, włączyła się trzecia średniowieczna siła, jaką były uniwersytety, zwłaszcza te, które posiadały dłuższe tradycje. Ich przedstawiciele tzw. starej szkoły (schola lub via antiqua), którzy reprezentowali trzynastowieczny uniwersalizm, mieli silne oparcie w filozofii realistycznej i w teologii spekulatywnej. W tym czasie utrzymywała się teoria papizmu ${ }^{6}$, według której papież był zastępcą Chrystusa na ziemi, posiadał władzę nie tylko duchową, lecz i świecka, był władcą absolutnym. Poza Tomaszem z Akwinu? podobne poglądy głosili Idzi z Rzymu (zm. 1316) ${ }^{8}$, Jakub z Viterbo (zm. 1308) ${ }^{9}$, Augustyn z Ankony (Augustinus Triumphus, zm. $1328)^{10}$, Henryk z Kremony (zm. 1312 ${ }^{11}$ ) i Jan Quidort z Paryża (zm. 1306) ${ }^{12}$. Niemniej już u niektórych trzynastowiecznych dekretystów ${ }^{13}$ i teologów jak

${ }^{5}$ R. Scholz, Die Publizistik zur Zeit Philipps des Schönen und Bonifaz' VIII. Ein Beitrag zur Geschichte der politischen Anschauungen des Mittelalters, Stuttgart 1903, s. 1-31.

${ }^{6}$ J. R o h l s, Geschichte der Ethik, Tübingen 1991, s. 160.

${ }^{7}$ R. S chol z, Die Publizistik zur Zeit Philipps des Schönen und Bonifaz' VIII. Ein Beitrag zur Geschichte der politischen Anschauungen des Mittelalters, Stuttgart 1903, s. 69, 119.

${ }^{8} \mathrm{Id} \mathrm{z} \mathrm{i} \mathrm{z} \mathrm{R} \mathrm{z} \mathrm{y} \mathrm{m} \mathrm{u,} \mathrm{De} \mathrm{regimine} \mathrm{principum} \mathrm{libri} \mathrm{III} \mathrm{(traktat} \mathrm{powstał} \mathrm{ok.} \mathrm{1280,} \mathrm{druko-}$ wany w 1473 r.), De renuntiatione papae (powstał w 1297 r., czéściowo drukowany), De ecclesiastica sive de summi pontificis postetate (powstał w. $1301 \mathrm{r}$ ). $-\mathrm{R}$. S c h ol z, Die Publizistik..., s. 32-68.

${ }^{9} \mathrm{Jakub}$ z Vite $\mathrm{rb}$, De regimine christiano (powstal w $1301 \mathrm{r}$.). - $\mathrm{R}$. Scholz, Die Publizistik..., s. 129-152.

in Agosiino Trionío, Summa de potestate papae (powstata w 1320 r.). R. Scholz, Die Publizistik..., s. 172-174; K. Hirsch, Die Ausbildung der konziliaren Theorie im XIV. Jahrhundert, Wien 1903, s. 3-9.

${ }^{11}$ Henryk z Cremony, De potestate papae (powstal w 1301 r.). - R. Scholz, Die Publizistik..., s. 152-165; druk także s. 459-471.

${ }_{12}$ Jan Q uid ort, De regia potestate et papali (powstał w 1303 r.). - R. S c hol z, Die Publizistik..., s. 275-333.

${ }_{13}$ Papa „a nemine est iudicandus, nisi dephenditur a fide devius”. Decretum Gratiani, d. $40 \mathrm{c} 6$. 
np. u dominikanina Jana Quidorta pojawiła się myśl o możliwości odwołania papieża $w$ przypadku głoszenia herezji ${ }^{14}$. Problem ten podjęli niektórzy myśliciele XIV wieku. Wywodzili się oni zarówno z tradycyjnych jak i nowych kierunków filozoficznych.

$Z$ tych pierwszych, którzy byli realistami, wypada wymienić przynajmniej awerroiste Marsyliusza z Padwy (zm. przed 1343). W napisanym w 1324 roku dziele Defensor pacis ${ }^{15}$ spopularyzował on arystotelesowską doktrynę o naturalnym powstaniu państwa ${ }^{16}$. Wystapił $\mathrm{z}$ radykalnym poglądem, że prawodawcą ziemskim jest lud, który także ustanawia prawo ${ }^{17}$. Sobór powszechny powinien też reprezentować wolę suwerennego ludu ${ }^{18}$. Marsyliusz z Padwy podsunął myśl o nowej idei soborowej, według której władcy świeccy jako przedstawiciele wiernych mogą zwoływać sobór ${ }^{19}$, który jest najwyższym organem Kościoła pojętego jako społeczeństwo wiernych i który posiada pełne prawo decydowania w sprawach zarówno administracyjnych jak i dogmatycznych ${ }^{20}$. Była to więc oparta na laicyzmie awerroistycznym teoria o niezależności władzy świeckiej od duchownej ${ }^{21}$.

Jan Wyklif (zm. 1384) w filozofii był skrajnym realista. Jako teolog był radykalnym reformatorem. Twierdził on bowiem, że tylko Pismo św. jest jedyną regułą wiary ${ }^{22}$ i że Chrystus sam jest głową całego Kościoła, pojętego jako wspólnotę przeznaczonych do zbawienia. We Wyklifowej koncepcji Kościoła, wykluczającej episkopat z papieżem na czele i uznającej tylko urząd parafialny, nie ma żadnej istotnej różnicy między klerem i laikatem ${ }^{23}$. W soborze mogli uczestniczyć tak pierwsi jak i drudzy. Jan Wyklif, będąc przeciwnikiem monarchizmu papieskiego, opowiadał się za podporządkowaniem spraw kościelnych państwu ${ }^{24}$.

Niezależnie od realistów starej szkoły podstawy doktrynalne dla koncyliaryzmu przygotowali także niektórzy nominaliści XIV wieku. Ich wielcy przywódcy, Wilhelm z Ockham i Jan Burydan utworzyli nową szkołe (schola lub via nova względnie moderna). Średniowieczni moderniści, jak ich

${ }^{14}$ H. S molinsky, Konstanz. W: Theologische Realenzyklopädie, XIX, Berlin, New York 1990, s. 579.

${ }^{15}$ E. Gils on, Historia filozofii chrześcijańskiej w wiekach średnich. Przełożył A. Z a le w s k i, Warszawa 1966, s. 511-512; K. H i r s c h, Die Ausbildung..., s. 20-33.

${ }^{16} \mathrm{~L}$. de Lagarde, La naissance de l'esprit ladi'que au déclin de Moyen Age. III: Marsile de Padoue ou le premier théoricien de l'Etat ladi'que, Saint Paul Trois Châteaux 1934, s. 118-138 i $212-213$.

${ }^{17}$ J. R o h 1 s, Geschichte..., s. 163.

${ }^{18}$ R. S cholz, Die Publizistik..., s. 452-455.

${ }^{19} \mathrm{~K}$. H i r s c h, Die Ausbildung..., s. 25.

${ }^{20} \mathrm{Ch}$. H. L o h r, Modelle für die Überlieferung theologischer Doktrin: Von Thomas von Aquin bis Melchior Cano. W: Dogmengeschichte und katholische Theologie. Hrsg. W. L ös e r, K. Le h m a n n, M. L u t z-B a c h m a n n, Würzburg 1985, s. 153.

${ }^{21}$ M. Ż y w c z y ń s ki, Papiestwo i papieże w średniowieczu, Kraków 1995, s. 69.

${ }^{22}$ Ch. H. L o h r, Modelle..., s. 161.

${ }^{23}$ Tamże, s. 164-166.

${ }^{24} \mathrm{~S}$. S w i e ż a w k i, Eklezjologia późnośredniowieczna na rozdrożu, Kraków 1990, s. 27. 
też nazywano, nie byli wcale zainteresowani w ratowaniu dawnego uniwersalizmu. Wystapili oni z koncepcją in dy w i d u a 1 i z m u. Jego nowe idee nie ograniczyły się bynajmniej do domeny doktrynalnej. Wnet zaczęły także przenikać do sfery życia umysłowego, społecznego, państwowego, a nawet kościelnego.

W wyniku krytycznego rewizjonizmu przedstawicieli nowej szkoły na znaczeniu straciła dotąd podtrzymywana teoria papizmu ${ }^{25}$. Nawiązali zaś do myśli Jan Quidorta o możliwości odwołania papieża w przypadku głoszenia herezji ${ }^{26}$. Dzięki temu mogli snuć rozważania nad k oncyliaryzme m ${ }^{27}$. Do tego przyczynił się konceptualista Wilhelm z Ockham (zm. ok. 1349). W napisanym w 1334 roku „Dialogu”28 stał się radykalnym przedstawicielem poglądów, że źródłem władzy jest lud, pojęty w myśl czternastowiecznego indywidualizmu jako zespół jednostek ${ }^{29}$, który wzięty jako całość jest nieomylny ${ }^{30}$. W sprawach dotyczących Kościoła poszedł od Marsyliusza z Padwy o wiele dalej ${ }^{31}$. Twierdził nawet, że w Kościele bez szkody może być więcej papieży i że wielu ludzi może kierować Kościołem bez papieża. Przez to podsunął późnośredniowieczną ideę soborową ${ }^{32}$. Według niej sobór powszechny jako reprezentant zbioru jednostkowych wiernych górował nad papieżem, co więcej, mógł być zwołany nawet przez ludzi świeckich, którzy w przypadku udowodnienia papieżowi herezji mogli nawet pozbawić go urzędu $^{33}$. Okhamowska koncepcja koncyliaryzmu przekazywała pełnię władzy kościelnej ludziom wierzącym ${ }^{34}$.

Gdy w 1378 roku wybuchła wielka schizma zachodnia ${ }^{35}$, powstało na Uniwersytecie Paryskim pytanie, kto jest prawdziwym papieżem. Na drodze

${ }^{25} \mathrm{~J}$. R o h 1s, Geschichte der Ethik, Tübingen 1991, s. 160.

${ }^{26}$ H. S m ol in s k y, Konstanz. W: Theologische Realenzyklopädie, t. 19, s 579.

${ }^{27} \mathrm{~K}$. H ir s c h, Die Ausbildung..., s. 67.

$28 \mathrm{Wilhelm} \mathrm{z} \mathrm{Ockham}$, Dialogus inter magistrum et discipulum. W: Me 1ch i or Gold ast (ed.), Monarchia S. Romani Imperii, II, Hannover 1668, s. 339-957; por. K. H irs ch, Die Ausbildung..., s. 42; B. Ti erney, Origins of Papal Infallibility, 1150-1350, Leiden 1972, s. 205-237. - Wypada zauważyć, że pierwsze wydanie Dialogu ukazało się w Lyonic 1494 r. Londyńska reedycja tego dzieła pochodzi z 1962 r. Por. J. Gi 1, Konstanz und Basel-Florenz, Mainz 1967, s. 23 (= Geschichte der ökumenischen Konzilien, wyd.: G. D u m e i g e, H. B a ch t, IX).

${ }^{29}$ J. R o h 1 s, Geschichte..., s. 161-163.

${ }^{30} \mathrm{~K}$. H ir s h, Die Ausbildung..., s. 43.

31 B. Ti e rney, Conciliarism (History of). W: New Catholic Encyclopedia, t. 4, Washington 1967 (reprint: 1981), s. 110.

32 „iila igitur congregatio essei conciiium generale repuianda, in qua diversae personate gerentes auctoritatem et vicem universarum partium totius sanitatis [zamiast: christianitatis] ad tractandum de communi hono rite conveniunt". - Wilh el m z Ockh a m, Dialogus..., s. 603-604; por. K. H ir s c h, Die Ausbildung.... s. 45.

${ }^{33}$ K. S c hol z, Die Publizistik..., s. 456-457.

${ }^{34}$ K. H i r s ch, Die Ausbildung..., s. 50.

${ }^{35}$ F. S ch e uffgen, Beiträge zu der Geschichte des großen Schismas, Freiburg 1889, s. 17; A. K n e e r, Die Entstehung der Konziliaren Theorie, Rom 1893, s. 9 (= Supplementheft der römischen „Quartalschrift für christliche Altertumskunde und Kirchengeschichte”). 
prawnej usiłował je rozstrzygnąć wicekanclerz i profesor teologii Uniwersytetu Paryskiego, Henryk z Langenstein (zm. 1397) w „Epistola pacis”36. $\mathrm{W}$ jego koncyliarystycznych poglądach opartych na burydanowskim terminizmie i reizmie występuje koncepcja Kościoła jako wspólnoty ogarniającej wszystkich wiernych (tota congregatio fidelium).

Chociaż okhamowski konceptualizm nie był oficjalnie wykładany na Uniwersytecie Paryskim, to jego idee miały jednak cichych zwolenników wśród niektórych teologów nastawionych koncyliarystycznie. Pod wpływem nowej szkoły pozostawali $\mathrm{m}$. in. Konrad z Gelnhausen (zm. 1390), Piotr d'Ailly (zm. 1420) i Jan Gerson (zm. 1429). Pierwszy z nich napisał najpierw Epistola brevis ${ }^{37}$, a potem „Epistola concordiae ${ }^{38}$, w których to dziełach po raz pierwszy w 1380 roku przedstawił teorię soboru powszechnego ${ }^{39}$. Według niej sobór powszechny posiada najwyższy kościelny autorytet ${ }^{40}$. Kościół posiada dwie głowy duchowe, z których główna jest Chrystus, a drugą jest papież jako jego zastępca ${ }^{41}$. To rozróżnienie jak i odwołanie się do zgody wiernych i zasady suwerenności ludu umożliwiało w wyjątkowych przypadkach bez zgody papieża zwołanie soboru powszechnego ${ }^{42}$, który wszakże nie jest nieomylny ${ }^{43}$. Podana przez Konrada $\mathrm{z}$ Gelnhausen definicja soboru powszechnego jest parafrazą okhamowskiego określenia. Teoria Konrada opierała się też na indywidualizmie czternastowiecznego nominalizmu, według którego to, co jest dobre dla jednostki, musi być korzystne także dla całej grupy. Za zwołaniem soboru powszechnego opowiedziała się większość profesorów Uniwersytetu Paryskiego ${ }^{44}$. Według Piotra d'Ailly ${ }^{45}$ i Jana Gersona sobór był nawet koniecznością ${ }^{40}$.

${ }^{36} \mathrm{~J}$. A s c h b a c h, Geschichte der Wiener Universität, t. 1, Wien 1865, s. 366-402.

${ }^{37}$ H. K a i s e r (ed.), ,Historische Vierteljahrschrift", 3:1900, s. 381-394; A. P o s c h, Konrad v. Gelnhausen. W: Lexikon für Theologie und Kirche, t. 6, Freiburg im Br. 1958, kol. 463.

${ }^{38} \mathrm{M}$ a r tè n e, Thesaurus novus anecdotorum, t. 11, Paris 1717, kol. 1200-1226.

${ }^{39}$ "Concilium generale est multarum vel plurium personarum rite convocatarum repraesentatium vel gerentium vicem diversorum statuum, ordinum et sexuum vel personarum totius christianitatis venire aut mittere valentium aut potentium ad tractandum de bono communi universalis ecclesiae in unum locum communem congregatio". - Tamże, kol. 1217.

40 „Sancta mater Ecclesia catholica et universalis, cuius concilium generale est reputatum [zamiast: representativum], superior collegio Cardinalium [est), quorum factum fidem et totius Ecclesiae statum tangens in dubium et quaestionem vertitur, nec est in terris alius superior, ad quem in hoc casu haberi valeat recursus". - Tamże, kol. 1208.

${ }_{41}$ "Huius autem almae matris universalis Ecclesiae duo sunt vel esse debent capita subordinata spiritualia: unum quidem principale semper sanum et indefectibile Christus Deus noster, fidei verus rector [...] Aliud est caput Ecclesiae secundarium scilicet papa, qui est vicarius primi capitis Christi [...] quo deficiente sive in esse naturae sive in esse gratiae nihilominus corpus et membra vivunt". - Tamże, kol. 1215.

${ }^{42}$ K. H i r s c h, Die Ausbildung..., s. 77.

${ }^{43}$ Tamże, s. 79.

${ }^{44}$ Tamże, s. 81 .

${ }^{45}$ Tamże, s. 82-84.

${ }^{46}$ F. M a c h i l e k, Das grosse abendländische Schisma in der Sicht des Rudolf von Sagan. W: R. B ä u m e r (ed.), Das Konstanzer Konzil, Darmstadt 1977, s. 93. 
Radykalny koncyliaryzm XIV wieku opierał się więc z jednej strony na awerroistycznym realizmie Marsyliusza z Padwy i skrajnym realizmie Jan Wiklefa, a z drugiej strony na konceptualizmie Wilhelma z Ockham i terminizmie Jana Burydana. Niezgodne z nauką Kościoła doktrynerstwo wyklifizmu oddziałało najwcześniej i bezpośrednio na Uniwersytet Praski ${ }^{47}$, gdzie jego zapalonymi zwolennikami w niektórych sprawach stali się Hieronim z Pragi (zm. 30.5.1416) ${ }^{48}$ i Jan Hus (zm. 4.7.1415) ${ }^{49}$. O ile ten ostatni propagował tradycyjne poglądy katolickie w sprawie episkopatu, kapłaństwa, spowiedzi, indulgencji, eucharystii, obcowania świętych, o tyle zapatrywania Jana Wyklifa były w niektórych przypadkach heterodoksyjnymi innowacja$\mathrm{mi}^{50}$. Ta orientacja doktrynalna nie miała szansy przebicia się na piętnastowiecznych soborach reformatorskich, gdzie większość skłaniała się do czternastowiecznego nominalizmu. Wobec tego okhamowski i burydanowski indywidualizm znalazł się u podstaw koncyliaryzmu soborów powszechnych pierwszej połowy XV wieku.

Po erekcji Wydziału Teologii Akademii Krakowskiej w 1397 roku $^{51}$ biskup krakowski Piotr Wysz z Radolina (zm. 1414) dążenia reformatorskie rozciągnął na życie Kościoła powszechnego. W tym względzie wspierał go Mateusz z Krakowa (zm. 1410), który był profesorem teologii wspomnianego fakultetu od jesieni 1397 do wiosny 1399 roku. Chociaż mieli oni różne wykształcenie filozoficzne, przyświecał im ten sam cel. Piotr studiował filozofię w szkołach erfurckich. Chcąc zmniejszyć toczące się spory filozoficzne pomiędzy zwolennikami starej i nowej drogi, zaproponował jeszcze trzecią drogę, którą nazwał w s póln ą droga (via communis). Miała ona opierać się zinterpretowanym awerroistycznie arystotelizmie ${ }^{52}$. Przywiezione przez

${ }^{47} \mathrm{P} . \mathrm{S}$ pu n a r, V. H e ro $1 \mathrm{~d}$, L'Université de Prague et le rôle des disputions de quolibet à sa faculté des Arts à la fin du XIV et au début du XV siècle. W: Soixante-neuvième session annuelle du Comité, Union Académique Internationale, Prague, du 11 au 17 juin 1995, Bruxelles, s. 32.

${ }^{48} \mathrm{Ch}$. J. H e fe l e, H. L e c le r c q, Histoire des conciles d'après les documents originaux, t. 7, cz. 1, Paris 1916, s. 377-408; F. Š m a h e 1, Hieronymus von Prag. Forschung ohne Probleme und Perspektiven?, „Historica”, 13:1966, s. 81-111; V. H e r o ld, Die Polemik mit der Prager „hussitischen” Auffassung der platonischen Ideen in der Handschrift der Universitätsbibliothek Leipzig 1445. W: Husitstvi-Reformace-Renesance. Sbornik $k$ 60. narozeninám Františka Sm Františka Šmahela, Praha 1994, s. 581.

${ }^{49}$ V. He rold, Die Philosophie des Hussitismus. Zur Rolle der Ideenlehre Platons. W: M. B en edikt, R. Kn oll, J. Rup itz, K. Ko hle n berger, W. S e it t e r (ed.), Verdrängter Humanismus, verzögerte Aufklärung. I, 1: Philosophie in Österreich (1400-1650). Vom Konstanzer Konzil zum Auftreten Luthers. Vom Beginn der Reformation bis zum westfä-

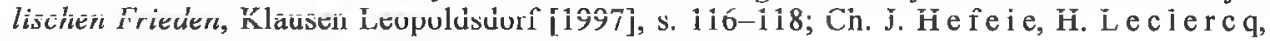
Histoire..., s. 110-166, 251-296, 298-350, 519-528.

${ }_{50}^{50}$ P. D e Vooght, Hussiana, Louvain 1960, s. 5.

${ }^{51}$ M. Markowski, Dzieje Wydziatu Teologii Uniwersytetu Krakowskiego $w$ latach 1397-1525, Kraków 1996, s. 48.

52 "Tertio sciendum, quod conclusiones hic positae quasi omnes possunt allegari ex littera Aristotelis, super quam conformiter sunt disputatae quia via communis principaliter trahitur ex dictis Philosophi et Commentatoris". - Petrus de Polonia, Quaestiones metaphysicae et philosophiae naturalis et totius logicae compendiose compilatae in Erffordia se- 
niego dzieła rekopiśmienne były przez niektórych filozofów studiowane w Krakowie ${ }^{53}$. W ten sposób niewielkie wpływy awerroizmu pojawiły się na pewien czas w krakowskiej filozofii. Spod pióra Piotra Wysza wyszły przynajmniej dwa traktaty reformatorskie. Jeden $\mathrm{z}$ nich, który zaczyna się od słów: „Omnium hominum...”, powstał w 1401 roku. Jego do tej pory nie odnaleziono ${ }^{54}$. W 1404 roku zaś napisał „Speculum aureum" ${ }^{\text {"55 }}$. Był współautorem „De praxi Romanae Curiae" ${ }^{\text {} 36}$. W swoich poczynaniach reformatorskich opierał się na autorytecie Pisma św., dekretach kościelnych i argumentach zasadzających się na przyrodzonym rozumie ludzkim (ratio naturalis) ${ }^{57}$. Jego krytyka była skierowana przeciw Kurii Rzymskiej, którą należałoby zreformować ${ }^{58}$, i przeciwko papieżowi ${ }^{59}$, którego za uprawianie symonii należałoby zdjąć $\mathrm{z}$ urzędu ${ }^{60}$. Mimo to Kościół rzymski uważał on za matkę i nauczycielkę wszystkich pozostałych kościołów ${ }^{61}$.

Mateusz z Krakowa, który studiował filozofię i teologię na Uniwersytecie Praskim, był zwolennikiem umiarkowanego burydanizmu praskiego ${ }^{62}$. Za reformą Kościoła opowiedział się on już w Pradze. Na przełomie XIV i XV wieku współdziałał z Piotrem Wyszem, który pod względem prawnym uzupełnił napisane w 1403 roku dzieło „De praxi Romanae Curiae" ${ }^{\text {63 }}$. Jego zdaniem fundamentem Kościoła jest Kuria w Rzymie, a jego reprezentantem jest

cundum dicta concordantium in via communi, prologus. - M. M a r k ow s k i, Die philosophischen Anschauungen und Schriften des Peter Wysz von Polen, Lublin 1992, s. 125.

${ }_{53}$ M. Markowski, Erfurter mittelalterliche Handschriften in der Jagiellonischen Bibliothek in Krakau, die philosophischen Werke enthalten (w druku).

${ }^{54}$ Tenże, Dzieje Wydziatu Teologii..., s. 90.

${ }^{55}$ Tenże, Peter Wyschs Traktate über die Reform der Kirche des beginnenden 15. Jahrhunderts, „Studia Mediewistyczne", 31:1994, s. 71-89.

${ }^{56}$ Tenże, Piotr Wysz jako autor »Speculum aureum" $i$ wspótautor "De praxi Curiae Romanae". „Przegląd Uniwersytecki”, 5:1993 z. 2, s. 12-13.

${ }^{57}$ „Ut igitur ego ipse viribus exiguis militaturus sub vexillo Domini et indutus fortitudine Iesu Christi vestrae universitati concurrendi viam aperiam et aciem adversus inimicos Domini pugnae ponam, tria tanta mala germinantia prosequenda et persequenda pro praesenti aggredior, quae iuxta posse conabor machina triplici, scilicet auctoritate sacrae scripturae, ratione naturali et iure canonico dirigente Domino conterere, evellere et radicitus extirpare". Petrus Wysz de Radolin, Speculum aureum de titulis beneficiorum ecclesiasticorum. W: W. S e ńko, Piotr Wysz z Radolina (* ok. 1354 - +1414) i jego dzieło «Speculum aureum», Warszawa 1995, s. 74.

58 „Primo scilicet errores gravissimos Romanae curiae detegam circa provisiones beneficiorum et indulgentiarum concessiones detectosque eliminando cum simoniacis et corum participibus condemnabo". - Tamże.

59 „Et quasi inania reputantur sicque tota Romana curia a planta pedis usque ad verticem captis patenter erroribus excaecata". - Tamże.

60 "Tertio totam curiam erroneam et in statu damnationis laborantem ex verissimis fundamentis declarabo nec non omnes, qui a iure communi per exorbitantes gratias beneficia ecclesiastica sunt adepti, papae plenitudinem potestatis pertractando". - Tamże, s. 75.

${ }^{61} 61$ „Iam aperte video quod Romana ecclesia aliarum omnium rationabiliter esse debeat mater et magistra". - Tamże, s. 84 .

${ }^{62}$ M. Markowski, Źródła $i$ badania dziejów filozofii średniowiecznej $w$ Polsce, „Studia Warmińskie”, 27:1990, s. 100.

${ }^{63}$ Wydane w 1551, 1690, 1757 i 1969 r., po raz ostatni przez W. S eńkę, Mateusza z Krakowa "De praxi Romanae Curiae», Wrocław 1969, s. 72-122. 
papież rzymski ${ }^{64}$, który jest jednak odpowiedzialny przed jego członkami ${ }^{65}$. $Z$ powyższego wynika, że ani Piotr Wysz, ani Mateusz $z$ Krakowa nie byli zwolennikami radykalnego koncyliaryzmu czternastowiecznego.

Po Jagiellońskiej fundacji Uniwersytetu Krakowskiego jego pierwsi filozofowie wprowadzili doń praskie prądy życia umysłowego. Dopiero około 1415 roku - i to chyba pod wpływem wydarzeń na soborze w Konstancji zaczęli tworzyć rodzimą orientację doktrynalną. Nawiązywała ona z jednej strony do metodologicznej postawy zaproponowanej przez Piotra z Radolina, czyli do tzw. wspólnej drogi, a z drugiej do tej orientacji burydanizmu, który reprezentował Mateusz z Krakowa $\mathrm{i}$ inni prascy wychowankowie ${ }^{66}$. Krakowska wspólna droga propagowała jedność intelektualną w dawnych doktrynach i zgodę w sporach religijnych ${ }^{67}$. Do utrwalenia tej drogi jako pewnej postawy metodologicznej na Uniwersytecie Krakowskim przyczynił się jego rektor i wybitny przedstawiciel polskiej szkoły prawa narodów ${ }^{68}$, Paweł Włodkowic z Brudzenia (zm. 1436). Gdy na soborze w Konstancji wystąpił z nauka o tolerancji, naturalnej równości i wolności człowieka ${ }^{69}$, to właśnie wyszedł on z metodologicznych założeń wspólnej drogi ${ }^{70}$. Gdy na tym soborze dowodził, że papież posiada jurysdykcję zarówno duchowa jak i ziemską, to od-

64 „Nemo autem est, qui dubitet, Sedem Apostolicam et Curiam eius Romanam esse radicem et fundamentum totius ecclesiae, Domino in Evangelio dicente: Tu es Petrus et super hanc petram aedificabo ecclesiam meam. Declaratur hoc clarius diversorum canonum institutis, quod ipsa sancta Romana ecclesia super omnes alias ecelesias principatum obtinet, utpote omnium mater christifidelium et magistra, II qu. VII Ad Romanam, De privilegiis ant., De electi fundamenta et De poenis felicis I. VI. Et ob hoc debeat esse iurium conditrix, propagatrix spiritualium, correctrix malorum, directrix errantium, persecutrix vitiorum, iustitiae et virtutum prosecutrix, oppressorum defensio, relevatrix pauperum, rectificatio et reformatio deformiter inordinatorum, doctrix errantium, morum exemplar, magistra et ministra omnis boni, regula agendorum. Ipsa est enim, quae supremam habet clavium potestatem, et ad quam pro talibus, etiamsi diu alibi quaerantur, finaliter recurritur. Ibi namque quaeritur plena absolutio criminum, amotio scrupulorum conscientiarum serenatio, discussio dubiorum, terminatio lituum declaratio et determinatio veritatum", - tamże, Matthaei de Cracovia, De praxi Romanae Curiae, tamże, s. 74-75.

${ }^{65} \mathrm{Mateusza}$ z K rak ow a, «De praxi Romanae Curiae», s. 72-122.

${ }^{66}$ M. Markowski, Burydanizm w Polsce w okresie przedkopernikańskim. Studium $z$ historii filozofii i nauk ścistych na Uniwersytecie Krakowskim w XV wieku, Wrocław 1971, s. 201-203.

${ }^{67}$ M. M a r k o w sk i, Metodologia nauk. Dzieje filozofii średniowiecznej w Polsce, t. 2 , Wrocław 1976, s. 148, 160, przyp. 63.

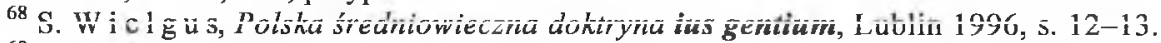

69 "Antequam veniam ad solutionem quaestionis secundae, sciendum, quod licet illustres patres Innocentius et Hostiensis videntur esse contrarii, et omnes communiter valentissimi utriusque iuris doctores in suis scriptis sequuntur patrem iurium Innocentium salvis inferius dicendis, ideo sapiendo communem scholam expeditis omnibus opinio Hostiensis recitabitur et suis rationibus sufficienter respondebitur". - Magistri Pauli Vladimiri Tractatus de potestate papae et imperatoris respectu infidelium, ed. M. B o b r z y ń s ki. W: Starodawne prawa polskiego pomniki, t. 5, Cracoviae 1878, s. 165.

${ }^{70}$ M. M ark ow ski, Metodologia nauk..., s. 147. 
wołał się do powszechnie przyjętego zdania doktorów prawa kanonicznego $\mathrm{i}$ teologi ${ }^{71}$. Jednym $\mathrm{z}$ pierwszych propagatorów via communis $\mathrm{w}$ uniwersyteckim środowisku krakowskim był wybitny filozof i teolog oraz autor traktatu na sobór bazylejski, Benedykt Hesse (zm. 1456) ${ }^{72}$. Odwołania do tej postawy metodologicznej wystepuja u niego już w napisanym w ostatnich latach drugiego dziesięciolecia XV wieku komentarzu do „Isagoge" Porfiriu$\mathrm{sza}^{73}$. Podobne odniesienia Hessego do wspólnej drogi spotyka się w jego późniejszych komentarzach ${ }^{74}$ do takich dzieł Arystotelesa jak "O duszy” ${ }^{75}$ i „Fizyka" ${ }^{\circ}$. Wielki autorytet naukowy Benedykta Hessego sprawił, że jego uczniowie aż do połowy XV wieku opowiadali się za programem wspólnej drogi na Uniwersytecie Krakowskim. W filozofii oznaczało to trzymanie się umiarkowanej orientacji burydanizmu ${ }^{77}$. W wykładach teologii przeważało korzystanie $\mathrm{z}$ takich dzieł $\mathrm{z}$ zakresu teologii jak Communis lectura Pragensis $^{78}$ bądź tzw. krakowski komentarz do Sentencji Piotra Lombarda zaczynający się od słów: „Utrum Deus gloriosus..." "79 , bądź obszerny komentarz Marsyliusza z Inghen do „Sentencji” Piotra Lombarda ${ }^{80}$. W krakowskiej teologii wybił się augustynizm nominalizujący.

W krakowskiej filozofii i teologii pierwszej połowy XV wieku dużą rolę odgrywał indywidualizm nowej szkoły zapoczatkowany w poprzednim

71 "Quamvis ad investigandum terrestris monarchiae fundamenta se multa ingenia occuparunt, haec tamen opinio magis est veritati consona, et etiam est communior doctorum sententia, scilicet papam habere utramque iurisdictionem, spiritualium et temporalium. Quam opinionem constat esse fulcitam non solum in iure canonico, sed etiam naturali et divino". Magistri Pauli Vladimiri, Tractatus de potestate papae et imperatoris respectu infidelium, s. 189-190.

${ }_{72}$ M. M a rk ow sk i, Metodologia nauk..., s. 145.

73 „De secundo dicitur quod communis via dicit, quod loyca est ars factiva". - Benedykt Hesse z K rakowa, Quaestiones super "Isagogen»Porphyrii, Kraków, BJ, rkps 1900, k. $4 \mathrm{v}$.

${ }^{74}$ M. M a rk ow ski, Metodologia nauk..., s. 145.

75 „Sed tamen secundum communem viam et probabiliorem opinionem respondetur ad questionem per istam conclusionem". - Benedykt Hesse z K rakowa, Quaestiones disputatae "De anima» Aristotelis, Kraków, BJ, rkps 2013, k. 167r.

76 „Et solita fieri per communem scolam”. - Tenże, Quaestiones super octo libros "Physicorum» Aristotelis, Kraków, BJ, rkps 1367, k. 44ra, i rkps 2376, k. 114v. - Benedykt Hesse z Krakowa, Quaestiones super octo libros "Physicorum» Aristotelis. Wydał, wstępem i komentarzami opatrzył S. Wielgus, Wrocław 1984. -222 .

${ }^{77}$ M. Markowski, Burydanizm w Polsce w okresie przedkopernikańskim, s. 209-

${ }^{78}$ A. Półtawski, Communis lectura Pragensis, „Mediaevalia Philosophica Polonorum", $1: 1958$, s. 11-23.

${ }^{79}$ M. M a r kow s k i, Metodologia nauk..., s. 141; Z. Włodek, Krakowski komentarz $z X V$ wieku do "Sentencji» Piotra Lombarda. W poszukiwaniu tendencji doktrynalnych na Wydziale Teologicznym Uniwersytetu Krakowskiego w XV wieku. Cz. 2: Tendencje doktrynalne Komentarza krakowskiego, „Studia Mediewistyczne”, 9:1968, s. 286.

${ }^{80}$ M. M a r k ow s k i, Znajomość komentarza Marsyliusza z Inghen do "Sentencji» Piotra Lombarda u krakowskich teologów średniowiecznych, „Analecta Cracoviensia”, 29:1997, s. 53-64. 
stuleciu. W zwiqzzku z tym w centrum zainteresowań znalazł się konkretny człowiek. Wzięto to pod uwage także w koncepcji nauki. Ażeby mogła ona służyć człowiekowi, preferowano nauki praktyczne. Praktycyzm miał przyczyniać się do dobrobytu człowieka. Służąca kontemplacji metafizyka musiała ustapić miejsce filozofii przyrody ${ }^{81}$, co znalazło swój wyraz w n at u ra li zm i e zmierzającym do lepszego poznania świata. W tym przypadku refleksja koncentrowała się nad konkretnymi rzeczami i ich właściwościami, co zapoczątkowało reizm ${ }^{82}$. W antropologii filozoficznej najwyższą wartością bowiem stał się konkretny człowiek, który czujac się wolnym obywatelem świata i ufając swoim przyrodzonym zdolnościom, rozwinął k r y ty c y z m ${ }^{83}$. Znalazł on swój oddźwięk nawet w krakowskiej teologii. Uczestnik soboru bazylejskiego i profesor teologii Mikołaj z Kozłowa odniósł się krytycznie do tych teologów, którzy w tej dziedzinie wiedzy nawiazują do Arystotelesa jako autorytetu ${ }^{84}$. W teorii naukowego poznania na znaczeniu straciło kryterium prawdy obiektywnej. Zadowolono się zaś przekonaniem subiektywnym, czemu sprzyjał okhamowski konceptualizm i burydanowski terminizm. Lansowany przez przedstawicieli nowej i wspólnej drogi subiektywizm sprawił, że wiarygodne jest to przekonanie subiektywne, na które zgadza się wielu ludzi lub większość jednostek. Tym samym ich przyrodzony rozum (ratio naturalis) nabrał dużego znaczenia przy rozstrzyganiu ważkich problemów. Był to przejaw śmiałej działalności nominalistycznych dialektyków, którzy przez to mogli się uniezależnić od odwoływania się od prawd biblijnych i rozstrzygnięć teologicznych, które prezentowali uznani dokto$\mathrm{rzy}^{85}$. W wyniku tego doszło do wyraźnego oddzielenia rozumu i wiary. Tym kryterium kierowali się też przedstawiciele soborów reformatorskich pierwszej połowy XV wieku. O ile w filozofii było ono narzędziem walki z autorytetem Arystotelesa, o tyle na wspomnianych soborach legło ono u podstaw rozstrzygnięć eklezjologicznych. W takim przypadku autorytet papieża został podporządkowany subiektywnemu osądowi ojców soborowych, uważających

${ }^{81}$ M. Markowski, Die neue Physik an der Krakauer Universität im XV Jahrhundert. W: Antiqui und Moderni. Traditionsbewusstsein und Fortschrittsbewusstsein im späten Mittelalter, Berlin 1974, s. 501-508 (= Miscellanea Mediaevalia. Veröffentlichungen des Thomas-Instituts der Universität zu Köln, IX).

${ }_{82}^{8}$ M. M a rk ow ski, Die Eigenart des Individuellen im mitteleuropäischen Buridanismus des späten Mittelalters, in: Individuum und Individualität im Mittelatter, Berlin-New York 1996, s. 327-337 (= Miscellanea Mediaevalia. Veröffentlichungen des Thomas-Instituts der Universität zu Köln, XXIV).

${ }^{83} \mathrm{~K}$ M i rhalsk i, Filozofin wieków środnich, Kraków 1997, s. 207, 229-231.

84, ,Et illi, qui dicunt theologiam apprehendi non posse nisi praevio duc caeco Aristotele et praeeuntibus philosophis, viris privatis, qui vani facti sunt, quia operibus attendentes non cognoverunt, quis esset artifex eorum". - M i k ołaj z Kozłow a, Principium super I librum «Sententiarum», wyd. K. W o j c i k, Wykład wstepny Mikotaja Kozłowskiego do I księgi "Sentencji» Piotra Lombarda w rękopisie BJ 1525, „Materiały do Historii Filozofii średniowiecznej w Polsce", 1:1970, s. 129; M. M a r k ow s k i, Teoria poznania. Dzieje filozofii średniowiecznej w Polsce, t. 6 Wroclaw 1978, s. 124.

${ }^{85}$ Tamże, s. 131, 142, przyp. 47. 
się za reprezentantów ludzi wierzących. W teorii nauki zaszły zmiany nie tylko w jej klasyfikacji, lecz także w określeniu jej naukowego statusu: wartość naukową posiada także nauka prawdopodobna ${ }^{86}$. Probabilizm i prob a bi li or y z m, który stosowano w nauce, znalazł swój oddźwięk też w obradach soborowych. W nich bowiem kierowano się opinią ogółu lub większością jego uczestników ${ }^{87}$. Bardzo wzrosła rola etyki indywidualnej, w której mówi się także o doczesnym szczęściu jednostkowego człowieka, przez co w późnym średniowieczu pojawił się felicy tabiliz m ${ }^{88}$. Zmiany, które zaszły w filozofii, wpłynęły określająco na ujmowanie innych nauk. W wyniku tych przemian teologia spekulatywna musiała ustapić pod naporem teologii praktycznej i afektywnej, czemu zresztą sprzyjał utrzymujący się fi i e i z m.

Do powstania tych orientacji filozoficznych najbardziej przyczynił się Benedykt Hesse. $\mathrm{Z}$ nim współdziałał Wawrzyniec z Raciborza. Ich uczniowie Jan z Lgoty ${ }^{89}$, Tomasz ze Strzempina i Jakub z Paradyża rozwijali te założenia doktrynalne. $\mathrm{Na}$ porządku dziennym reformatorskich soborów pierwszej połowy XV wieku były wprawdzie takie sprawy jak usunięcie wielkiej schizmy, reforma Kościoła, troska o czystość wiary i inne doniosłe wydarzenia bieżące jak np. zatarg polsko-krzyżacki, ale u podstaw tych wielkich niedomagań tej epoki toczyła się także walka doktrynalna: ścierały się dwa potężne prądy umysłowe. Był to realizm skrajny i czternastowieczny nominalizm $\mathrm{w}$ dwóch odmianach, tj. jako burydanowski terminizm w filozofii $\mathrm{i}$ jako okhamowski konceptualizm w teologii, który bywa określany też jako augustynizm nominalizujący. Już od początku XV wieku zaczęło utrwalać się przekonanie, że pomiędzy zainicjonowaną przez Jana Wyklifa i podtrzymywaną na Uniwersytecie Praskim herezją a skrajnym realizmem metafizycznym istnieją ścisłe zwiazki ${ }^{90}$. W związku $\mathrm{z}$ tym $\mathrm{w}$ obieg puszczono nawet adagium: Universalia realia sunt haeresis seminaria ${ }^{91}$. Powstały w Pradze spór o rzeczywiste istnienie uniwersaliów nie był tylko czystym sporem metafi-

${ }^{86}$ M. Markowski, Probacja i perswazja jako formy argumentacji na Uniwersytecie Krakowskim $w$ XV wieku, „Studia Mediewistyczne”, XXVII, 27:1990 z. 1, s. 53-62.

${ }^{87}$ Tenże, Logika. Dzieje filozofii średniowiecznej w Polsce, I, Wrocław 1975, s. 90.

${ }^{88}$ Tenże, Doktryna homo felicitabilis na tle późnośredniowiecznych tendencji filozoficznych, „Studia Warmińskie”, 29:1992, [1996], s. 33-60.

${ }^{89}$ Mimo iż był koncyliarysta, opowiadał się za monarchizmem papieskim: „Sed quia inter omnes species politiae, quam ponit Aristoteles in libro Politicorum, scilicet aristocratiam, oligarchiam et regnum, regnum est melior species politiae, quae videlicet multitudo regitur per unum, quam aristocratia, qua multitudo regitur per paucos virtuosos, et quam oligarchia. qua regitur per plures, ex quo concludi videtur, quod tota multitudo ecclesiae debet regi regimine regni et ita unus in ea debet principari, videlicet papa". - I o a n n is E 1 got, Determinatio Basiliensis, Wyd. H. A n $\mathrm{zulew}$ icz. W: Polskie traktaty koncyliarystyczne $z$ potowy $X V$ wieku, wyd. W. B u c i c h ow s k i, Warszawa 1987, s. 68, w.13-20.

${ }^{90} \mathrm{~S}$. S w i èza w s k i, Dzieje filozofii europejskiej w XV wieku. 1: Poznanie, Warszawa 1974 , s. 84

${ }_{91}$ F. Šmahel, „Universalia realia sunt haeresis seminaria”. Filosofie pražskiho extremniho realismu ve svetle doktrinálne institucionálni kritiky, "Československy C̆asopis Historicky" 16:1968 z. 6, s. 797-818. 
zycznym, lecz także miał wielorakie powiazzania teologiczne. W wyniku tego to rozpalone zarzewiem sporów doktrynalnych środowisko uniwersyteckie najpierw opuściło wielu magistrów i studentów polskich, a w 1409 roku doszło do wielkiego wyjścia Niemców. Od tego czasu innym uniwersytetom europejskim nie mogły być obce praskie spory doktrynalne. Wobec nich wyraźne stanowisko zajęły uniwersytety: w Wiedniu już w 1410 roku $^{92}$, Heidelbergu w 1412 roku $^{93}$, Erfurcie ${ }^{94}$ i Kolonii w 1425 roku $^{95}$. Odgrywający dużą rolę na soborze w Konstancji Jan Gerson wiązał herezję wyklifizmu i husytyzmu ze skrajnie realistyczną koncepcją powszechników, którą w przeszłości wielokrotnie potępili paryscy biskupi i kanclerze uniwersyteccy ${ }^{96}$. Już w 1416 roku Piotr Wolfram w imieniu Uniwersytetu Krakowskiego wręczył soborowi konstancjańskiemu pismo pochwalające potępienie wyklifizmu i husytyzmu jako prądów nieortodoksyjnych ${ }^{97}$.

Potępienie poglądów Jana Husa i Hieronima z Pragi stanowiło wielką klęskę skrajnego realizmu pojęciowego, który wznowił Jan Wyklif, a było wspaniałym triumfem burydanowskiego terminizmu i okhamowskiego konceptualizmu. Zawzięta dyskusja na ten temat toczyła się aż do trzeciego ćwierćwiecza XV wieku na Uniwersytecie Krakowskim ${ }^{98}$. Gdy na znaczeniu straciła ideologia koncyliaryzmu, a umocnił się urząd papieża, to jednym

${ }^{92}$ Tamże, s. 817.

93 „Quod nullus [...] dogmatiset [...] perversa condempnaque dogmata Wycleff, etiam universalia realia, verum potius contraria". - F. E h rl e, Der Sentenzenkommentar Peters von Candia des Pisaner Papstes Alexanders V. Ein Beitrag zur Scheidung der Schulen in der Scholastik des vierzehnten Jahrhunderts und zur Geschichte des Wegestreites, Münster i. W. 1925, s. 173, przyp. 1 („Franziskanische Studien”, Beiheft IX).

${ }_{94}$, Nullus hic collegiatus dogmatizat in scholis publice aut private aliquam materiam, que directe vel indirecte tendat ad heresim seu ad perfidiam husanam aut universalia realia ut Platonici posuere aut opiniones teneant de pluralitatibus formarum realium in eodem supposito et similia". - E. K le in e id a m, Universitas Studii Erffordensis. Überblick über die Geschichte der Universität Erfurt im Mittelalter. Teil II: Spätscholastik, Humanismus und Reformation 146I-1521, Leipzig 1969, s. 185; cyt. S. S w i è a w s k i, Dzieje filozofii europejskiej $w X V$ wieku, t. 1, s. 84, przyp. 115.

${ }^{95}$ Exemplum adest de Pragensibus, quorum error ex tali doctrina emanavit". - F. J. von $\mathrm{B}$ i a c $\mathrm{o}$, Die alte Universität Köln und die späteren Gelehrten-Schulen dieser Stadt, Köln 1855 , s. 238-239.

96 „Die Behauptung des Daseins von solchen real-gegenständlichen Universalien ist in jüngster Zeit durch das heilige Konstanzer Konzil in der Stellungnahme gegen die den Flammentod gestorbenen Prager Hus und Hieronymus verurteilt worden". J o h a n n es Ge r s o n, Ober die Bedeutungsformen. Toil In: Die Utereintintiming der Metaphysin mit der Logik. 50 Thesen. W: Texte zum Universalienstreit. Band 2: Hoch- und spätmittelalterliche Scholastik. Lateinische Texte des 13.-15. Jahrhunderts übersetzt und herausgegeben von H.-U. W ö hle r, Berlin 1994, s. 222.

${ }^{97}$ K. M o rawski, Historia Uniwersytetu Jagiellońskiego. Średnie wieki i odrodzenie, t. 1, Kraków 1900, s. 147-148; M. M ark ow sk i, Uniwersytet Krakowski wobec idei soborowej $w X V$ wieku, s. 520.

${ }_{98}$ M. Mark ow ski, Problematyka uniwersaliów w polskich piętnastowiecznych pismach nominalistycznych, „Studia Mediewistyczne”, 12:1970, s. 73-166. 
z pierwszych jego pociagnięć stała się reforma nauczania filozofii. Papież Mikołaj V wysłał wnet do Paryża kardynała d'Estoutevilla, który opracował nowy program nauczania filozofii i w dniu 1 czerwca 1452 roku nadał opracowane w tym duchu statuty Wydziałowi Filozofii Uniwersytetu Paryskiego. Stąd filozofia realistyczna zaczęła przenikać do innych ośrodków nauczania filozofii ${ }^{99}$.

${ }^{99}$ Tenże, Burydanizm w Polsce w okresie przedkopernikańskim, s. 210 i n. 